\title{
Relaksasi Benson Dengan Masalah Kelelahan Pada Pasien Gagal Jantung di Rumah Sakit Islam Jakarta Cempaka Putih Jakarta Pusat Tahun 2020
}

\author{
Tri Endah Pangastuti Sudrajat, Febriana, Y.Kalvein M. Mangngi \\ Mahasiswa Spesialis KMB FIK UMJ \\ Email: endah_pangastuti77@gmail.com
}

\begin{abstract}
Abstrak
Relaksasi benson merupakan pengembangan metode respon relaksasi dengan melibatkan faktor keyakinan pasien, yang dapat menciptakan suatu lingkungan internal sehingga dapat membantu pasien mencapai kondisi kesehatan dan kesejahteraan lebih tinggi. Subyek intervensi pada pasien dengan gagal jantung dilakukan intervensi relaksasi benson selama 3 hari sebanyak 2 kali pada Pagi dan Sore hari. Evaluasi dilakukan dengan pre dan post perlakuan dengan cara menjawab pertanyaan langsung di kuisioner fatique severity scale (FSS) yang bersisi 9 pertanyaan/pernyataan. Jumlah total responden 60 pasien terdiri dari kelompok intervensi sebanyak 30 responden dan kelompok kontrol 30 responden Hasil penerapan ini menggambarkan bahwa sesudah dilakukan relaksasi benson dapat mempengaruhi penurunan tingkat kelelahan pada pasien gagal jantung dengan nilai $p$ value (nilai $p 0,000$ ) dan pada kelompok kontrol tidak mengalami perubahan dengan nilai $p$ value (nilai $p=0,073$ )
\end{abstract}

Kata Kunci: relaksasi benson, kelelahan

\begin{abstract}
Benson relaxation is the development of a relaxation response method involving patient belief factors, which can create an internal environment so that it can help patients achieve higher health and well-being conditions. Intervention subjects in patients with heart failure were subjected to benson relaxation intervention for 3 days 2 times in the morning and evening. The evaluation was carried out by pre and post treatment by answering the direct questions on the questionnaire Fatique Severity Scale (FSS) which had 9 questions/statements. The total number of respondents was 60 patients consisting of an intervention group of 30 respondents and a control group of 30 respondents. The results of this application illustrate that after Benson relaxation can affect the decrease in fatigue levels in heart failure patients with a $p$ value ( $p$ value 0.000 ) and the control group does not experience change with $p$ value ( $p$ value $=0.073$ )
\end{abstract}

Keywords: benson relaxation, fatique 


\section{Jurnal Bidang IImu Kesehatan}

\section{Pendahuluan}

Penyakit kronis merupakan masalah kesehatan menahun baik infeksi maupun non infeksi. Prevalensi penyakit kronis menurut World Health Organization (WHO) terutama penyakit tidak menular pada tahun 2014 adalah 14 juta. Hasil riset Kesehatan dasar Departemen Kesehatan Republik Indonesia (2013) terkait penyakit kronis terjadi peningkatan dibanding tahun sebelumnya terutama stroke $(0,83 \%)$ dan penderita penyakit jantung paling banyak terjadi pada aparatur sipil negara (ASN) yaitu pegawai pemerintahan, TNI-Polri, dan pegawai BUMN serta BUMD dengan prevalensi sebanyak 2,7 persen.. Data menunjukkan prevalensi penyakit jantung berdasarkan diagnosis dokter di Indonesia yaitu sebesar 1,5 persen dari total penduduk. Prevalensi penyakit jantung di DKI Jakarta berada pada urutan 5 di seluruh propinsi (Riskesdas, 2018). Di Indonesia sendiri menghadapi kedua permasalahan tersebut baik penyakit menular maupun tidak menular.

Peningkatan jumlah penyakit tidak menular (non-communicable disesases) secara global sedang terjadi seiring dengan menurunya jumlah penyakit menular (communicable disease) kondisi tersebut berkaitan dengan perubahan pola hidup dan manajemen kesehatan (WHO, 2016). Contoh penyakit tidak menular adalah diabetes mellitus, stroke dan penyakit kardiovaskular seperti gagal jantung. Penyakit kardiovaskular menjadi suatu masalah kesehatan utama di negara maju dan berkembang. Secara global ditemukan sebanyak 17,5 juta jiwa penderita penyakit kardiovaskuler. Sebanyak 58 juta angka kematian disebabkan penyakit jantung (WHO, 2016). Asia menempati peringkat jumlah penderita penyakit kardiovaskuler sebanyak 712.1 ribu jiwa. Sedangkan di asia tenggara, Indonesia menduduki peringkat kedua dengan jumlah 371 ribu jiwa (WHO, 2014).

Menurut Price \& Wilson 2007, gagal jantung kongestif merupakan kondisi patologis saat jantung tidak mampu memompa darah untuk memenuhi kebutuhan metabolism jaringan. Gagal Jantung kongestif merupakan sekumpulan tanda dan gejala kompleks dimana ditemukan perubahan struktur, fungsi dan neurohormonal (Úri, K., Fagyas, M., Mányiné Siket, I., Kertész, A., Csanádi, Z., Sándorfi, G., \& ... Lizanecz, E., 2014) yang mengarah pada ketidakmampuan jantung memompa darah untuk memenuhi kebutuhan metabolism tubuh. (Joshi \& Tirgar, 2013).

Manifestasi klinis pada pasien dengan gagal jantung kongestif adalah kelelahan, sesak napas, nadi cepat, intoleransi aktifitas, retensi cairan (Souza, V., Zeitoun, S. S., Lopes, C. T., Oliveira, A. D., Lopes, J. L., \& Barros, A. L., 2014), penurunan kadar oksigen darah arteri, edema paru, edema perifer, ketidaknyamanan (Riegel, B., Hanlon, A. L., 


\section{Jurnal Bidang IImu Kesehatan}

Xuemei, Z., Fleck, D., Sayers, S. L., Goldberg, L. R., \& Weintraub, W. S., 2013), dan gangguan pola tidur (Yancy et al., 2013).

Dampak kelelahan adalah penurunan kualitas hidup sehingga pasien tidak dapat melakukan aktifitas yang menunjang kehidupannya (self sustainability) yang pada akhirnya akan menurunkan kualitas hidup pasien dengan penyakit kronis. Penurunan kualitas hidup berarti kenaikan morbiditas dan mortalitas penyakit kronis. Dengan demikian menjadi penting untuk menjelaskan kelelahan pada penyakit kronis sebagai upaya penunjang dalam penyusunan strategi pengelolaan kelelahan pada penyakit kronis dengan tujuan akhir peningkatan kualitas hidup pasien dengan penyakit kronis.

Selain itu muncul permasalahan non fisik seperti ketakutan, kecemasan, depresi dan stress yang secara simultan dapat memperburuk kondisi pasien gagal jantung kongestif berkaitan dengan respon neurohormonal pasca stress. Kelelahan merupakan permasalahan fisik maupun psikologis yang ditemukan pada pasien gagal jantung. Kelelahan adalah ketidakberdayaan secara fisik maupun psikologis sehingga menyulitkan pasien untuk beraktifitas yang pada akhirnya akan terjadi penurunan produktifitas dan kualitas hidup pasien. Kelelahan terjadi akibat penurunan jumlah energi strategis tubuh sebagai konsekuensi dari penurunan sirkulasi di jaringan. Menurut penelitian Woung-Ru, T., Chiung-Yao, Y., \&
San-Jou, Y. (2010) menjelaskan bahwa salah satu predictor kelelahan pada pasien gagal jantung adalah kecemasan.

Penurunan produktivitas pada pasien gagal jantung disebabkan oleh kelelahan. Ketidakseimbangan antara suplai dan kebutuhan oksigen karena jantung gagal mempertahankan sirkulasi mengakibatkan terjadinya kelelahan (Smith, Kupper, De Jonge, \& Denollet, 2010). Kelelahan terjadi akibat penurunan kapasitas fsik pasien.

Gagal jantung dalam melakukan aktivitas sehari-hari yang berakibat menurunnya kemampuan pasien dalam meningkatkan kualitas hidupnya. Kelelahan merupakan salah satu gejala gagal jantung (Li-Huan, Chung-Yi, Shyh-Ming, Wei-Hsian, \& Ai-Fu, 2010). Pada pasien gagal jantung terjadi perubahan neurobiokimiawi sebagai respon kompensasi akibat gangguan yang terjadi. Penurunan curah jantung akan menyebabkan vasokonstriksi yang memperburuk sirkulasi sehingga kondisi perfusi perifer mengalami penurunan. Kondisi tersebut akan menyebabkan kelelahan pada pasien gagal jantung (WoungRu, Chiung-Yao, \& San-Jou, 2010).

Dalam relaksasi otot Benson, skor kelelahan berkurang setelah intervensi lebih dari kelompok kontrol. Terlepas dari efek psikologis, relaksasi memengaruhi sistem simpatis, yang akibatnya mengurangi beban kerja jantung dan meningkatkan curah jantung sebagai alasan utama kelelahan. 


\section{Jurnal Bidang IImu Kesehatan}

Latihan dapat memiliki efek menguntungkan pada hasil fisik pasien dengan gagal jantung.

Efek fisiologis dari relaksasi membantu dengan pengobatan gagal jantung seperti memblokir aktivitas kronis sistem simpatis. Relaksasi otot Benson mengurangi ketegangan otot, denyut jantung, tingkat kortisol, laju pernapasan, dan laktat darah melalui penciptaan suasana yang santai. Ini akibatnya mengurangi kelelahan. Yu et al menyoroti bahwa relaksasi otot progresif mengurangi tekanan psikologis, tetapi efektivitasnya pada kelelahan pada pasien dengan gagal jantung tidak terbukti. Hasil ini dapat dikaitkan dengan rendahnya kekuatan penelitian dalam identifikasi efek intervensi. Selain itu, perbedaan hadir dalam hasil Yu et al's studi dan penelitian ini dapat dicari dalam perbedaan antara jenis teknik relaksasi dan sampel. Efek dari teknik relaksasi otot Benson atau teknik relaksasi lainnya pada pasien dengan kondisi kronis dikonfirmasi oleh penelitian sebelumnya. Koushan et al melaporkan bahwa penerapan relaksasi otot Benson dua kali sehari (pagi dan sore) selama 20 menit selama 1 bulan mengurangi pengurangan kelelahan di antara pasien hemodialisis.

Efek relaksasi otot progresif pada kualitas tidur dan kelelahan dilaporkan pada pasien dengan kanker payudara yang menjalani kemoterapi, 32 penyakit paru obstruktif kronis, 33 dan multiple sclerosis. 34 Bjorneklett" et al 35 menyatakan bahwa intervensi yang mendukung seperti pendidikan, visualisasi mental, relaksasi otot, dan komunikasi nonverbal untuk 1 minggu, dengan tindak lanjut 4 hari, meningkatkan kualitas hidup pada pasien dengan kanker payudara dan mengurangi kelelahan setelah 2 bulan dibandingkan dengan kelompok kontrol. Meskipun demikian, tidak jelas bahwa apakah temuan penelitian dengan Bjorneklett" et al 35 adalah disebabkan oleh metode tertentu atau apakah itu disebabkan oleh efek sinergis dari berbagai intervensi.

Teknik relaksasi merupakan intervensi keperawatan yang dilakukan untuk mengatasi suatu masalah terutama akibat respon saraf simpatis. Berdasarkan nursing intervention classification (NIC) Domain physiological: basic, ada berbagai macam upaya relaksasi, diantaranya adalah teknik relaksasi otot progresif, napas dalam, pijat dan lain sebagainya. Maka dengan dilakukannya teknik relaksasi, diharapkan dapat menstimulasi saraf parasimpatis yang akan meredakan ketegangan pada otot, vasodilatasi dan yang paling utama adalah dapat mengatasi kelelahan.

Keperawatan profesional didunia berkembang sangat pesat, termasuk keperawatan di Indonesia. Keperawatan Indonesia sangat bergantung pada keberhasilan dalam melakukan perubahan mendasar pada pelaksanaan asuhan keperawatan, terutama yang ada di rumah sakit. Perubahan yang menunjukkan bahwa 


\section{Jurnal Bidang IImu Kesehatan}

memang benar keperawatan adalah sebuah profesi, dan asuhan keperawatan merupakan tindakan profesional dalam mengatasi masalah keperawatan. Sejalan dengan perkembangan ini, didasari benar bahwa untuk dapat melaksanakan asuhan keperawatan profesional dengan baik dan benar harus didasarkan ilmu dan kiat keperawatan yang terdapat dalam rumusan kompetensi perawat seorang profesiounal (Husin, 2013).

Pergeseran cara pandang tentang pelaksanan asuhan keperawatan professional berdasarkan kompetensi menjadi asuhan keperawatan berdasarkan bukti atau fakta yang dikenal sebagai Evidence Based Nursing Practice (EBNP). Asuhan keperawatan berdasarkan EBNP lebih menekankan pada kemungkinan keberhasilan asuhan keperawatan yang diperoleh dari hasil pengamatan cermat tindakan keperawatan yang digunakan dalam melaksanakan asuhan keperawatan yang diberikan. Dengan diterapkannya asuahan keperawatan berdasarkan EBNP memicu dilakukan riset keperawatan ilmiah yang lebih terarah pada upaya meningkatkan mutu asuhan keperawatan.

Pelayanan asuhan keperawatan kardiovaskuler merupakan salah satu bentuk pelayanan asuhan keperawatan spesialistik diantara beberapa pelayanan keperawatan spesialistik lainnya. Pelayanan asuhan keperawatan kardiovaskuler dilaksanakan oleh ners spesialis kardiovaskuler dalam upaya mengatasi masalah keperawatan kardiovaskuler yang dihadapi pasien. Dalam melaksanakan pelayanan asuhan keperawatan kardiovaskuler, ners spesialis harus berpikir kritis pada seluruh proses keperawatan.

\section{Pelaksanaan Inovasi}

Subyek intervensi yang telah dilakukan adalah Relaksasi Benson pada pasien dengan gagal jantung. Jumlah total responden 60 pasien terdiri dari kelompok intervensi sebanyak 30 responden dan kelompok kontrol 30 responden. Kelompok intervensi dilakukan di Ruang Rawat Inap yaitu ruang Matahari, Melati dan Arafah Atas sedangkan kelompok kontrol dilakukan di Ruang Rawat Inap yaitu ruang Matahari, Melati, Arafah Atas dan Rawat Jalan Polikilink Jantung.

Evaluasi relaksasi Benson dilakukan dengan pre dan post perlakuan. Evaluasi dilakukan dengan cara menjawab pertanyaan langsung di kuisioner FSS (fatique severitu scale) yang bersisi 9 pertanyaan/pernyataan. Rentang jawaban dari pertanyaan dalam bentuk skala likert jika pasien score 1 sampai dengn 7 . Responden menggunakan skala mulai dari 1 ("sangat tidak setuju") hingga 7 ("sepenuhnya setuju") untuk menunjukkan persetujuan mereka dengan sembilan pernyataan tentang kelelahan. Skala analog visual juga disertakan dengan skala tersebut; 


\section{Jurnal Bidang Ilmu Kesehatan}

responden diminta untuk menunjukkan kelelahan mereka selama 2 minggu terakhir dengan menempatkan tanda pada garis yang memanjang dari "tanpa kelelahan" menjadi "kelelahan yang bisa terjadi." Skor yang lebih tinggi pada skala mengindikasikan kelelahan yang lebih parah.

\section{Hasil}

\begin{tabular}{llllllll}
\hline $\begin{array}{l}\text { Varia } \\
\text { bel }\end{array}$ & $\begin{array}{l}\text { Karak } \\
\text { terist } \\
\text { ik }\end{array}$ & $\begin{array}{l}\text { Inte } \\
\text { rven } \\
\text { si }\end{array}$ & $\begin{array}{l}\text { Ko } \\
\text { ntr }\end{array}$ & $\begin{array}{l}\text { ol } \\
\text { o }\end{array}$ & $\begin{array}{l}\text { To } \\
\text { tal }\end{array}$ & \\
\hline Jenis & Laki- & 19 & 6 & 16 & 5 & 35 & 5 \\
kela & laki & 11 & 3 & 14 & 3 & 25 & 8 \\
min & pere & & 3 & & 4 & & 4 \\
& mpu & & 7 & & 7 & & 2 \\
& an & & & & & & \\
\hline Pendi & SD & 1 & 3 & 4 & 1 & 5 & 8 \\
dikan & SMP & 8 & 2 & 8 & 3 & 16 & 2 \\
& SMA & 10 & 7 & 11 & 2 & 21 & 7 \\
& PT & 11 & 3 & 7 & 7 & 18 & 3 \\
& & & 4 & & 3 & & 5 \\
& & & 3 & & 6 & & 3 \\
& & & 6 & & 2 & & 0 \\
& & & & & 4 & & \\
\hline Usia & Mini & 45 & & 44 & & & \\
& m & 68 & & 67 & & & \\
& Maks & & & & & & \\
& im & & & & & & \\
\hline
\end{tabular}

Karakteristik jenis kelamin yang paing banyak pada responden adalah laki-laki 58\% baik pada kelompok intervensi maupun kelompok kontrol, Karakteristik pendidikan kelompok intervensi dan kelompok control memiliki pendidikan yang bervariatif, tetapi lebih banyak keduanya memiliki pendidikan lebih banyak adalah SMA/sederajat $35 \%$ dan
Perguruan tinggi $30 \%$. Karakteristik usia kelompok intervensi dan kelompok kontrol memiliki persamaan yaitu usia dewasa akhir dan lansia (usia 44-68 tahun).

\begin{tabular}{|c|c|c|c|}
\hline $\begin{array}{c}\text { Kelompo } \\
k\end{array}$ & $\begin{array}{c}\text { Tingka } \\
\mathrm{t} \\
\text { Kelela } \\
\text { han }\end{array}$ & $\begin{array}{c}\text { Frekwen } \\
\text { si }\end{array}$ & Percent \\
\hline$\frac{\text { Interven }}{\underline{\text { si }}}$ & & & \\
\hline Sebelum & $\begin{array}{l}\text { ringan } \\
\text { Sedan } \\
\text { g }\end{array}$ & $\begin{array}{c}- \\
1 \\
29\end{array}$ & $\begin{array}{c}- \\
3,3 \\
96,7\end{array}$ \\
\hline Setelah & $\begin{array}{l}\text { Berat } \\
\text { Ringan } \\
\text { Sedan } \\
\text { g } \\
\text { Berat }\end{array}$ & $\begin{array}{c}6 \\
24 \\
-\end{array}$ & $\begin{array}{c}20 \\
80 \\
-\end{array}$ \\
\hline Kontrol & & & \\
\hline Sebelum & $\begin{array}{l}\text { Ringan } \\
\text { Sedan } \\
\text { g }\end{array}$ & $\begin{array}{c}6 \\
10 \\
14\end{array}$ & $\begin{array}{c}20 \\
33,3 \\
46,7\end{array}$ \\
\hline Setelah & $\begin{array}{l}\text { Berat } \\
\text { Ringan } \\
\text { Sedan } \\
\text { g } \\
\text { Berat }\end{array}$ & $\begin{array}{c}4 \\
10 \\
16\end{array}$ & $\begin{array}{l}13,3 \\
33,4 \\
53,3\end{array}$ \\
\hline
\end{tabular}

Kelompok intervensi ada penurunan tingkat kelelahan pada pasien gagal jantung sebelum dan setelah dilakukan intervensi relaksasi Benson yaitu; sebelum dilakuakan relaksasi benson 96,7 \% kelelahan berat dan kelelahan sedang 3,3\% setelah dilakuakan intervensi tingkat kelelahan berat $0 \%$ kelelahan sedang $80 \%$ dan kelelahan ringan $20 \%$. Pada kelompok kontrol terdapat perbedaan di hari pertama dan hari ketiga saat dilakukan evaluasi ada peningkatan kelelahan, khususnya yang mengalami 


\section{Jurnal Bidang Ilmu Kesehatan}

kelelahan yang sifatnya berat semakin meningkat dari yang semula $46,7 \%$ menjadi $53,3 \%$.

Nilai tingkat kelelahan kedua kelompok terdistribusi normal karena nilai $p>0.05$ sehingga analisis yang digunakan adalah uji t Test.

Tingkat kelelahan sesudah dilakukan intervensi mengalami penurunan yaitu nilai $p$ value (nilai $p \quad 0,000$ ) dapat disimpulkan bahwa ada pengaruh intervensi relaksasi benson terhadap tingkat kelelahan pada pasien gagal jantung di Rumah Sakit Islam Jakarta Cempaka Putih.

Tingkat kelelahan kelompok kontrol tidak mengalami perubahan dan dilihat dari nilai $p$ value (nilai $p=0,073$ ) dapat disimpulkan bahwa tidak ada pengaruh tingkat kelelahan pada kelompok kontrol.

\section{DISKUSI}

Penerapan ini menggambarkan bahwa sesudah dilakukan relaksasi benson dapat mempengaruhi penurunan tingkat kelelahan pada pasien gagal jantung dengan nilai $\mathrm{p}$ value (nilai p 0,000) dan pada kelompok kontrol tidak mengalami perubahan dengan nilai $p$ value (nilai $p=0,073$ ). Hal ini sejalan dengan penelitian Leila Seifi (2016) yang menunjukan bahwa terapi relaksasi benson menjadi metode alternative untuk menurunkan kecemasan pada passion gagal jantung. Terapi relaksasi benson ini tidak tidak mahal, tidak memiliki resiko yang besar.

\section{KESIMPULAN}

Pada kedua kelompok responden yaitu kelompok intervensi sebanyak 30 responden dan kelompok kontrol sebanyak 30 responden bahwa tingkat kelelahan sesudah dilakukan intervensi pada kelompok intervensi mengalami penurunan dengan nilai $p$ value $(p=0,000)$, maka dapat disimpulkan ada pengaruh intervensi relaksasi benson terhadap tingkat kelelahan pada pasien gagal jantung di Rumah Sakit Islam Jakarta Cempaka Putih. Sedangkan tingkat kelelahan pada kelompok kontrol tidak mengalami perubahan dengan nilai $p$ value $(p=0,073)$, maka dapat disimpulkan tidak ada pengaruh tingkat kelelahan pada kelompok kontrol.

Dengan hasil tersebut dapat disimpulkan bahwa intervensi relaksasi benson ada pengaruh terhadap penurunan tingkat kelelahan pada pasien jantung. Hal ini sangat penting bagi Perawat dalam memberikan asuhan keperawatan pada pasien gagal jantung dengan menurunkan tingkat kelelahannya.

\section{DAFTAR PUSTAKA}

1. Aalami, M., Jafarnejad, F., \& Modarres Gharavi, M. (2016). The effects of progressive muscular relaxation and breathing control technique on blood pressure during pregnancy. Iranian Journal of Nursing \& Midwifery Research, 


\section{Jurnal Bidang IImu Kesehatan}

21(3), 331-336. doi:10.4103/17359066.180382

2. Alternative \& Complementary Medicine, 19(5), 464-470. doi:10.1089/acm.2011.0873.

3. Black, J.M., \& Hawks, J.K. (2009). Medical surgical nursing: Clinical management for positive outcomes (Volume II, 7th Edition). Elsevier's Health Science Right Departement: Philadelphia.

4. Brunner \& Suddarth, (2013). Buku Ajar Keperawatan Medikal Bedah Edisi 8 volume 2. Jakarta EGC

5. Chandran, V., Bella, S., Schentang, C., \& Gladman, D. (2007). Fungtional assesment in chronic illnes therapyfatigue scale is valid in patients with psoriatric arthritis. Annals of Rheumatic Diseases, 66(7), 936-93.

6. Chen, W., Liu, G., Yeh, S., Chiang, M., Fu, M., \& Hsieh, Y. (2013). Effect of back massage intervention on anxiety, comfort, and physiologic responses in patients with congestive heart failure. Journal of

7. Correlates of fatigue in patients with heart failure. National Institute of health, Prog. Cardiovasc Nurs, 23(1), 1217.Figueroa, M.S., \& Jay, I.P. (2006).

8. Congestive eart failure: Diagnosis, pathophysiology, therapy, and implications for respiratory care. Respiratory Care, 51(4).
9. Crawford, M.H. (2009). Current Diagnosis \& Treatment Cardiologi (3rd Ed) McGraw-Hill Companies, Inc.

10. Chalder, T., Goldsmith, K. A., White, P. D., Sharpe, M., \& Pickles, A. R. (2015). Rehabilitative therapies for chronic fatigue syndrome: a secondary mediation analysis of the PACE trial. The Lancet Psychiatry, 2(2), 141-152.

11. Chan, J. S., Ho, R. T., Chung, K. F., Wang, C. W., Yao, T. J., Ng, S. M., \& Chan, C. L. (2014). Qigong exercise alleviates fatigue, anxiety, and depressive symptoms, improves sleep quality, and shortens sleep latency in persons with chronic fatigue syndrome-like illness. Evidence-Based Complementary and Alternative Medicine, 2014.

12. Chan, J. S., Li, A., Ng, S. M., Ho, R. T., Xu, A., Yao, T. J., ... \& Chan, C. L. (2017). Adiponectin Potentially Contributes to the Antidepressive Effects of Baduanjin Qigong Exercise in Women With Chronic Fatigue Syndrome-Like Illness. Cell transplantation, 26(3), 493-501.

13. Campo, R. A., Agarwal, N., LaStayo, P. C., O’Connor, K., Pappas, L., Boucher, K. M., ... \& Kinney, A. Y. (2014). Levels of fatigue and distress in senior prostate cancer survivors enrolled in a 12-week randomized controlled trial of Qigong.Journal of Cancer Survivorship, 8(1), 60-69. 


\section{Jurnal Bidang IImu Kesehatan}

14. European Journal of Heart Failure. (2014). European Society of Cardiology, 16 (Suppl. 2), 5-365 Guyton, A. C. and Hall, J. E. (1997). Buku Ajar Fisiologi Kedokteran Edisi 9. Jakarta: EGC.

15. Hayes, D. Ansted, M.I. \& Barbara, J.H. (2009). Insomnia and Chronik Heart Failure. Heart Fail Rev, 14: 171-182. Diunduh pada 02 Mei 2013.

16. Herlofson, L., \& Larsen, J. P. (2002). Measuring fatigue in patients with Parkinson's disease - the fatigue severity scale. European Journal of Neurology, 9, 595-600.

17. Hudak dan Gallo. 2011. Keperawatan Kritis: Pendekatan Asuhan Holistik. Edisi VIII Jakarta: EGC

18. Hashemzadeh, A.M.T., Farshi, G., Halabianloo, G.R., \& Rad, M. (2011). The study of effectiveness of relaxation and distraction techniques training in anxiety reduction in cardiac patients. Arak Medical University Journal, 14(3), 97-105.

19. Kleinman, L., Zodet, M. W., Hakim, Z., Aledort, J.,Barker, C., Chan, K., Krupp, L., \& Revicki, D. (2000).Psychometric evaluation of the fatigue severity scale for use in chronic hepatitis C. Quality of Life Research,9, 499-508.

20. Krupp, L. B., LaRocca, N. G., Muir-Nash, J., \& Steinberg, A. D. (1989). The fatigue severity scale: application topatients with multiple sclerosis and systemic lupus
erythematosus.Archives of Neurology, 46 , 1121-1123.

21. Li-Huan, C., Chung-Yi, L., Shyh-Ming, S., Wei-Hsian, Y., \& Ai-Fu, C. (2010). Predictors of fatigue in patients with heart failure. Journal of Clinical Nursing, 19(11/12), $1588-1596$ doi:10.1111/j.1365-2702.2010.03218.x.

22. Malisa, N., Ibrahim, K., \& Mardiah, W. Pengaruh Relaksasi Benson terhadap Fatigue pada Pasien Hemodialisis di RS Dustira cimahi. DAFTAR ISI, 225.

23. Naess, H., Waje-Andreassen, U. Thomassen, L., Nyland, H., \& Myhr, K. M. (2006). Health-related quality of life among young adults with ischemic stroke on zongter follow-up. Stroke, 37, 12321236

24. Newberg and Warldman. (2013). World can change your brain. American Journal of Clinical Hypnosis Vol. 56, Iss. 1, 2013.

25. Outcalt, S. D., Kroenke, K., Krebs, E. E., Chumbler, N. R., Wu, J., Yu, Z., \& Bair, M. J. (2015). Chronic pain and comorbid mental health conditions: independent associations of posttraumatic stress disorder and depression with pain, disability, and quality of life. Journal of behavioral medicine, 38(3), 535-543.

26. Seifi Leila, et.all (2018) Comparison of the Effects of Benson Muscle Relaxation and Nature Sounds on the Fatigue in Patients With Heart Failure, Holistic nursing practice Wolters Kluwer Health 


\section{Jurnal Bidang Ilmu Kesehatan}

27. Smeltzer, S.C., Bare, B.G., Hinkle, J.L., \& Cheever, K.H. (2010). Brunner and Suddarth's Text Book of Medical Surgical Nursing. $\left(11^{\text {th }}\right.$ ed). Lippincott Williams \& Wilkins, Inc.

28. Schneider, R. A. (2004). Chronic renal failure: assessing the fatigue severity scale for use among caregivers. Journal of Clinical Nursing, 13 (2), 219-225. Téllez, N., Río, J., Tintoré, M., Nos, C., Galán, I., \& Montalban, X. (2006). Fatigue in multiple sclerosis persists over time.Journal of Neurology, 253 (11), 1466-1470.

29. Smith, O. F., Kupper, N., de Jonge, P., \& Denollet, J. (2010). Distinct trajectories of fatigue in chronic heart failure and their association with prognosis. European Journal of Heart Failure, 12 (8), 841-848. doi:10.1093/eurjhf/hfq075.

30. Smith, O.F., van den Broek, K.C., Renkens, M., \& Denollet, J. (2008). Comparison of fatigue levels in patients with stroke and patients with end-stage heart failure: Application of the fatigue assessment scale. Journal of The American Geriatrics Society, 56(10), 1915-1919. doi:10.1111/j.15325415.2008.01925.x.
31. Younossi, Z. M., Stepanova, M., Nader, F., \& Henry, L. (2016). Patient-Reported Outcomes of Elderly Adults with Chronic Hepatitis C Treated with Interferon-and Ribavirin-Free Regimens. Journal of the American Geriatrics Society, 64(2), 386393.

32. Younossi, Z., \& Henry, L. (2015). Systematic review: patient-reported outcomes in chronic hepatitis C-the impact of liver disease and new treatment regimens. Alimentary pharmacology \& therapeutics, 41(6), 497-520.

33. Yuliana, A. (2012). Hubungan Self Care dan Defresi Dengan Kualitas Hidup Pasien Heart Failure di RSUP.Prof $\mathrm{Dr}$ Kandou Manado. Fakultas IImu http.//lontar.ui.ac.id.

34. Woung-Ru, T., Chiung-Yao, Y., \& San-Jou, Y. (2010). Fatigue and its related factors in patients with chronic heart failure. Journal of Clinical Nursing, 19(1/2), 69 78. doi:10.1111/j.1365-270 
Jurnal Bidang Ilmu Kesehatan 